\title{
A FILOSOFIA POLÍTICA DA RELIGIOSIDADE AFRO-BRASILEIRA COMO PATRIMÔNIO CULTURAL AFRICANO
}

\author{
José Carlos Dos Anjos*
}

\begin{abstract}
Resumo: Para marcar a pertinência de se ressaltar a existência de uma filosofia política na religiosidade afro-brasileira capaz de propor um outro equacionamento para o senso de equidade racial, o artigo aproxima o modo de lidar com as diferenças nos terreiros à sofisticada elaboração filosófica deleuziana de um pensamento das diferenças. Este artigo se desdobra em duas dimensóes: numa primeira explora-se uma concepção de pessoa estritamente vinculada ao modo afro-brasileiro de trabalhar as diferenças; por fim, retiramse consequiências político-filosóficas desse trato sofisticado das diferenças para uma rediscussão do significado do multiculturalismo no Brasil. $\mathrm{O}$ argumento principal deste artigo é o de que a religiosidade afro-brasileira vem expondo outra possibilidade de articulação das diferenças etnico-raciais e essa emergência se constitui como uma outra cosmopolítica divergente das que até aqui informam o sentido de nação.
\end{abstract}

Palavras-chave: Religiosidade Afro-brasileira, Pessoa, Racialização, Cosmopolítica.

Abstract: To mark the relevancy of standing out the existence of a political philosophy in the afro-Brazilian religiousness capable to consider another topic for the sense of racial equality, this article approaches the differences in the terreiros with the sophisticated philosophical elaboration deleuziana about a thought of differences. This article divided itself in two dimensions: firstly, it is explored a conception from person who is strictly linked to the afro-Brazilian way of working about differences; finally, it is removed political-philosophical consequences from this sophisticated treatment of the differences to a re-discussion about the meaning of the multiculturalism in Brazil. The main argument of this article is that the afro-Brazilian religiousness comes displaying another possibility of articulation for the ethnical-racial differences and this emergency is another cosmopolitics different from those that just inform the sense of nation.

Keywords: Afro-brasilian religiousness, Person, Racialization, Cosmopolitics.

\footnotetext{
* Pós-Doutor pela École Normale Superieure de Paris, ENSP, França e Professor Adjunto da UFRGS.
}

Debates do NER, Porto Alegre, ANo 9, N. 13, P. 77-96, JAN./Jun. 2008 